The Journal of Agricultural

Science

\section{cambridge.org/ags}

\section{Crops and Soils Research Paper}

Cite this article: McCabe CP, Burke JI (2021). Oat (Avena sativa) yield and grain fill responses to varying agronomic and weather factors. The Journal of Agricultural Science 159, 90-105. https://doi.org/10.1017/

S0021859621000320

Received: 27 November 2020

Revised: 8 March 2021

Accepted: 14 March 2021

First published online: 28 April 2021

\section{Keywords:}

Cultivar; N rate; oat; plant growth regulator; seed rate

\section{Author for correspondence:}

C. P. McCabe,

E-mail: cathalmccabe81@gmail.com

\title{
Oat (Avena sativa) yield and grain fill responses to varying agronomic and weather factors
}

\section{P. McCabe ${ }^{1,2}$ (D) and J. I. Burke ${ }^{1,2}$}

${ }^{1}$ UCD Lyons Farm, Lyons Estate, Celbridge, Naas, Co., Kildare, Republic of Ireland and and ${ }^{2}$ School of Agriculture and Food Science, University College Dublin, Belfield, Dublin 4, Republic of Ireland
(C) The Author(s), 2021. Published by Cambridge University Press. This is an Open Access article, distributed under the terms of the Creative Commons Attribution licence (http://creativecommons.org/licenses/by/4.0/), which permits unrestricted re-use, distribution, and reproduction in any medium, provided the original work is properly cited.

\section{CAMBRIDGE} UNIVERSITY PRESS

\begin{abstract}
Factorial experiments were carried out on spring- and winter-sown oat crops in Ireland in 2016-2019 to identify plant responses in yield formation and grain filling procedures. Two cultivars (Husky and Keely), three seed rates $\left(250,350\right.$ and 450 seeds $/ \mathrm{m}^{2}$ ), six applied nitrogen (N) rates $(40,70,100,130,160$ and $190 \mathrm{~kg} \mathrm{~N} / \mathrm{ha})$ with a plant growth regulator (PGR) were examined in spring and winter sowings, using the same cultivars at five rates of applied $\mathrm{N}(80$, $110,140,170$ and $200 \mathrm{~kg} \mathrm{~N} / \mathrm{ha})$. The applied $\mathrm{N}$ rate and seed rate significantly $(P<0.05)$ modified the yield components determining grains $/ \mathrm{m}^{2}$ in spring- and winter-sown crops with increases in panicle number of key importance. Increases were also observed in the proportion of primary grain by weight $(0.9-1.6 \%)$ and number $(0.7-1.4 \%)$ ratios in spring-sown crops in response to applied $\mathrm{N}$ rate, with winter-sown crops exhibiting a more consistent pattern of grain fill. Seed rate and PGR application had minor effects on yield components and panicle conformation. Grain fill procedures played an important role in the maximization of grain yield under seasonal conditions. Significant positive correlations were observed between the number of aborted grain sites and yield under drought conditions (0.22), with negative associations observed in near-optimal conditions $(-0.22$ to -0.41$)$. Agronomic effects on grain site abortion were minimal in comparison with seasonal effects. In seasons characterized by cool, consistent conditions, grain yield was maximized by the utilization of all available grain sites. Where assimilate shortages were encountered during grain fill the abortion of grains sites was positively associated with grain yield.
\end{abstract}

\section{Introduction}

Grain yield in oats is predominantly determined by grain number (Peltonen-sainio et al., 2007; Finnan and Spink, 2017) with grain weight of lower importance. Annual cereal crops respond to environmental variation through changes in grain number with grain weight a more stable characteristic (Sadras, 2007). The response of oats to environmental variation is therefore reflected in the plasticity of the key yield components responsible for the determination of total grain number (Mahadevan et al., 2016) with the following oat-specific hierarchy suggested: tiller number $>$ grains/panicle $>$ panicle number $>$ grain weight, indicating the relative flexibility of tiller number and the stability of grain weight. This hierarchy may also transfer to the capacity of an oat crop to respond to changes in agronomic practices. Sowing date (Wall and Cartwright, 1976; Crampton et al., 1997), cultivar (Brinkman and Rho, 1984; Buerstmayr et al., 2007), seed rate (Peltonen-sainio et al., 1997; Browne et al., 2006; Finnan et al., 2018), applied nitrogen $(\mathrm{N})$ rate (Ohm, 1976; Browne et al., 2006; Pecio and Bichonski, 2010; Finnan et al., 2019a) and plant growth regulator (PGR) (Leitch and Hayes, 1989; Browne et al., 2006) are all key agronomic parameters which have been shown to influence yield formation in oat crops. Establishing the impact of agronomic practices on the components contributing to total grain number and grain weight is a key target of this study.

Marshall et al. (2013) note the unique prevailing climatic conditions in Ireland which facilitate the autumn planting of spring oat genotypes and leads to the production of the highest average oat yield in the EU-27. Information on the differences in yield formation processes of oats sown in the winter or spring is lacking and requires elucidation. Modern cultivars are characterized by a high grain number (Peltonen-sainio et al., 2007) and an ability to maintain grain weight in an acceptable range (Calderini et al., 1997) whereas there has also been a decrease in plant height in modern cultivars (Lynch and Frey, 1993) reducing lodging susceptibility. There is also debate as to whether increasing the seed rate of crops is economical due to the ability of cereal crops to achieve a yield stability across a range of seed rates (Finnan et al., $2019 a, b)$.

The rate of applied $\mathrm{N}$ has been widely shown to be a key yield determining factor in oat production, (Chalmers et al., 1998; Burke et al., 2001; Browne et al., 2003). This is associated with increases in total grain number through increases in panicles $/ \mathrm{m}^{2}$ and spikelets/ear in oats with negative effects on single grain weight and increases in crop lodging (Chalmers et al., 
1998; Browne et al., 2006; Finnan and Spink, 2017). Modern cultivars may have a reduced susceptibility to lodging at higher levels of applied $\mathrm{N}$, which is the main deterrent of high levels of fertilizer $\mathrm{N}$ use on oat crops (Burke et al., 2001). On the topic of the susceptibility of oat crops to lodging, White et al. (2003) states that the application of PGR to oat crops is regarded as a necessity under Irish conditions. However, there are rising concerns about pesticide residues in food, with chlormequat frequently detected at levels below the maximum residue limit in oat samples (Reynolds et al., 2004). Investigating the effect of applied $\mathrm{N}$ rate and PGR application on modern varieties forms a key element of this study.

The oat is quite unique amongst cereal crops due to its panicle-type inflorescence and the ability to adjust grain number during grain fill through the processes of grain site abortion and tertiary grain production (Browne et al., 2006). The oat spikelet is also unique as it usually contains one to three florets that are in a primary, secondary and tertiary ranking, based on their position within the spikelet (White, 1995; Doehlert et al., 2005). Primary grains are the largest with kernel size reduced as the order increases. Takeda and Frey (1980) and Doehlert et al. (2002) state that most oat spikelets contain two grains, containing primary and secondary florets. It has been accepted that the distribution of grain size in oat lots fits a bimodal distribution as a result of this physiological feature (Symons and Fulcher, 1988; Doehlert et al., 2002; Doehlert et al., 2004). This variation in oat grain size presents difficulties for the oat milling processes as grains of different sizes will dehull at different rotor speeds (Deane and Commers, 1986; White and Watson, 2010). Increases in spikelet and total grain number are widely linked with an increased grain yield in oats (Peltonen-sainio et al., 2007), but the influence that these increases may have on grain fill procedures within the spikelet is unclear. Finnan and Spink (2017) suggested that grain yield in oats is limited by assimilate availability during grain fill. They further commented that increases in grain number are linked with an increased spikelet number at high yield levels rather than an increased level of secondary and tertiary grain formation, as demonstrated by Browne et al. (2003). Further examination into the procedures of grain filling at high grain yield levels is required in order to clarify this relationship between high grain number and grain filling procedures.

Browne et al. (2006) reported on the unique ability of the oat panicle to alter the number of potential grain sites by controlled abortion and the modification of the number of available tertiary grain sites based on the supply of assimilates during the grain fill period. Doehlert et al. (2002) reported that competition for photosynthate between a large grain number resulted in the abortion of grain sites in North Dakota. Browne et al. (2006) also reported cultivar and applied $\mathrm{N}$ rate effects on grain site abortion under Irish conditions. Identifying the grain fill procedures and levels of grain site abortion on oat panicles as potential grain number increases was a key target in the current study. Clarification of the role grain site abortion can play in maintaining grain yield during the periods of assimilate shortage will also be discussed.

The objective of the reported study was to re-evaluate the current understanding of the yield formation of oats under cool mild conditions, as typically experienced in Ireland. All yield components and panicle conformation measurements were recorded, with the examination of tertiary grain formation and postanthesis abortion a key research focus.

\section{Materials and methods}

This research was conducted in the east of Ireland with full site details provided in Table 1. 'Spring-sown' oat crops were sown at two sites in 2016 and at one site in 2017 and 2018, with 'wintersown' crops at a single site in 2017, 2018 and 2019. Therefore, comparisons between sites also involves different growing seasons and although the term 'site' is used through this document, the growing season aspect is recognized as being an important element within this. All sites had been in long-term continuous arable cropping for 15-20 years with optimal soil types for producing high yielding, high-quality oats. Soils with a possibility of a high mineralization of $\mathrm{N}$ were avoided based on cropping history (Wall and Plunkett, 2016) (Table 2). Meteorological data including monthly precipitation and mean daily temperatures were obtained from Met Eireann (www.met.ie). Rainfall and temperature data were sourced from locations within $5 \mathrm{~km}$ of the experiments.

\section{Experimental design}

The experimental design was a split plot layout of three replications for the spring sowings in 2016 and winter sowings in 2017 at Backweston, with all other sowings having four replications. Main plots consisted of two cultivars (Husky and Keely) and three seed rates $\left(250,350\right.$ and 450 seeds $\left./ \mathrm{m}^{2}\right)$, with an applied $\mathrm{N}$ rate included as the split plot, and a $+/-$ PGR application applied only to spring sowings. Plots were $15 \mathrm{~m}$ long with a 1 $\mathrm{m}$ discard to avoid fertilizer overlap.

\section{Crop husbandry}

Seedbeds were prepared using a reversible mouldboard plough to a depth of approximately $25 \mathrm{~cm}$ and a tilth was created using a power harrow. Seed was weighed out to target plant populations according to expected germination levels and thousand grain weight (TGW) values. All sowings were made by using a $1.5 \mathrm{~m}$ Wintersteiger XL plot drill (Wintersteiger AG, Austria) equipped with Lemken double-disc seed coulters (Lemken GmbH, Alpen, Germany) with a row spacing of $150 \mathrm{~mm}$. A single certified seed lot for each cultivar was used in each year. All spring sowings received insecticides for aphid control. Fungicides and herbicides were applied at recommended rates and timings.

\section{In-field assessments and operations}

All spring sowings received a pre-planting compound blend supplying $40 \mathrm{~kg} \mathrm{~N} / \mathrm{ha}, 20 \mathrm{~kg} \mathrm{P} / \mathrm{ha}$ and $50 \mathrm{~kg} \mathrm{~K} / \mathrm{ha}$. Winter sowings received $50 \mathrm{~kg} \mathrm{~N} / \mathrm{ha}, 20 \mathrm{~kg} \mathrm{P} / \mathrm{ha}$ and $60 \mathrm{~kg} \mathrm{~K} / \mathrm{ha}$ in early spring when ground conditions facilitated fieldwork. The remaining applied $\mathrm{N}$ was applied at growth stage (GS) 21 (Zadoks et al., 1974) in the form of $27.5 \%$ calcium ammonium nitrate to bring the $\mathrm{N}$ allocation up to the prescribed total levels of 40,70,100, 130,160 and $190 \mathrm{~kg} \mathrm{~N} / \mathrm{ha}$ in spring-sown experiments and 80 , $110,140,170$ and $200 \mathrm{~kg} \mathrm{~N} / \mathrm{ha}$ in winter-sown experiments. Plant growth regulation was applied as chlormequat chloride and Trinexapac-ethyl at 1.2 litres/ha +0.1 litres/ha at GS 30 and GS 32/33 (Zadoks et al., 1974).

At 6 weeks after planting, all emerged shoots were counted along a $1 \mathrm{~m}$ stick in three locations/plot and average plants $/ \mathrm{m}^{2}$ calculated by multiplying by a factor of 8 (eight rows $/ \mathrm{m}$ ). The number of panicles bearing stems was similarly recorded after anthesis. Prior to 
Table 1. Experimental site description

\begin{tabular}{llllll}
\hline Site & Site code & Trial year & Location & Previous cropping & Soil type \\
\hline Spring sowings & & & & & \\
\hline Collegeland, Moynalvey, Co., Meath & Site $1(\mathrm{~S})$ & 2016 & $53.4^{\circ} \mathrm{N},-6.7^{\circ} \mathrm{W}$ & Winter wheat & Patrickswell series: limestone derived till \\
\hline Newcastle, Co., Dublin & Site $2(\mathrm{~S})$ & & $53.3^{\circ} \mathrm{N},-6.5^{\circ} \mathrm{W}$ & Winter barley & Straffan series: fine loamy drift with limestone \\
\hline Moynalvey, Co., Meath & Site $3(\mathrm{~S})$ & 2017 & $53.5^{\circ} \mathrm{N}, 6.7^{\circ} \mathrm{W}$ & Spring wheat & $\begin{array}{l}\text { Dunboyne series: limestone and shale drift and lrish } \\
\text { Sea drift }\end{array}$ \\
\hline Collegeland, Moynalvey, Co., Meath & Site 4(S) & 2018 & $53.5^{\circ} \mathrm{N}, 6.7^{\circ} \mathrm{W}$ & Winter wheat & Patrickswell series: limestone till \\
\hline Winter sowings & & & & & \\
\hline Backweston, Leixlip, Co., Kildare. & Site $1(\mathrm{~W})$ & 2017 & $53 .{ }^{\circ} \mathrm{N},-6.5^{\circ} \mathrm{W}$ & Forage maize & $\begin{array}{l}\text { Donaghcumper series: derived from limestone and } \\
\text { some drift material }\end{array}$ \\
\hline Backweston, Leixlip, Co., Kildare & Site 2(W) & 2018 & $53.3^{\circ} \mathrm{N},-6.5^{\circ} \mathrm{W}$ & Spring faba beans & Great soil group: grey brown podzolic \\
\hline Arodstown, Moynalvey, Co., Meath & Site 3(W) & 2019 & $53.5^{\circ} \mathrm{N},-6.7^{\circ} \mathrm{W}$ & Winter barley & Patrickswell series: limestone derived till \\
\hline
\end{tabular}

Table 2. Site fertility and crop development

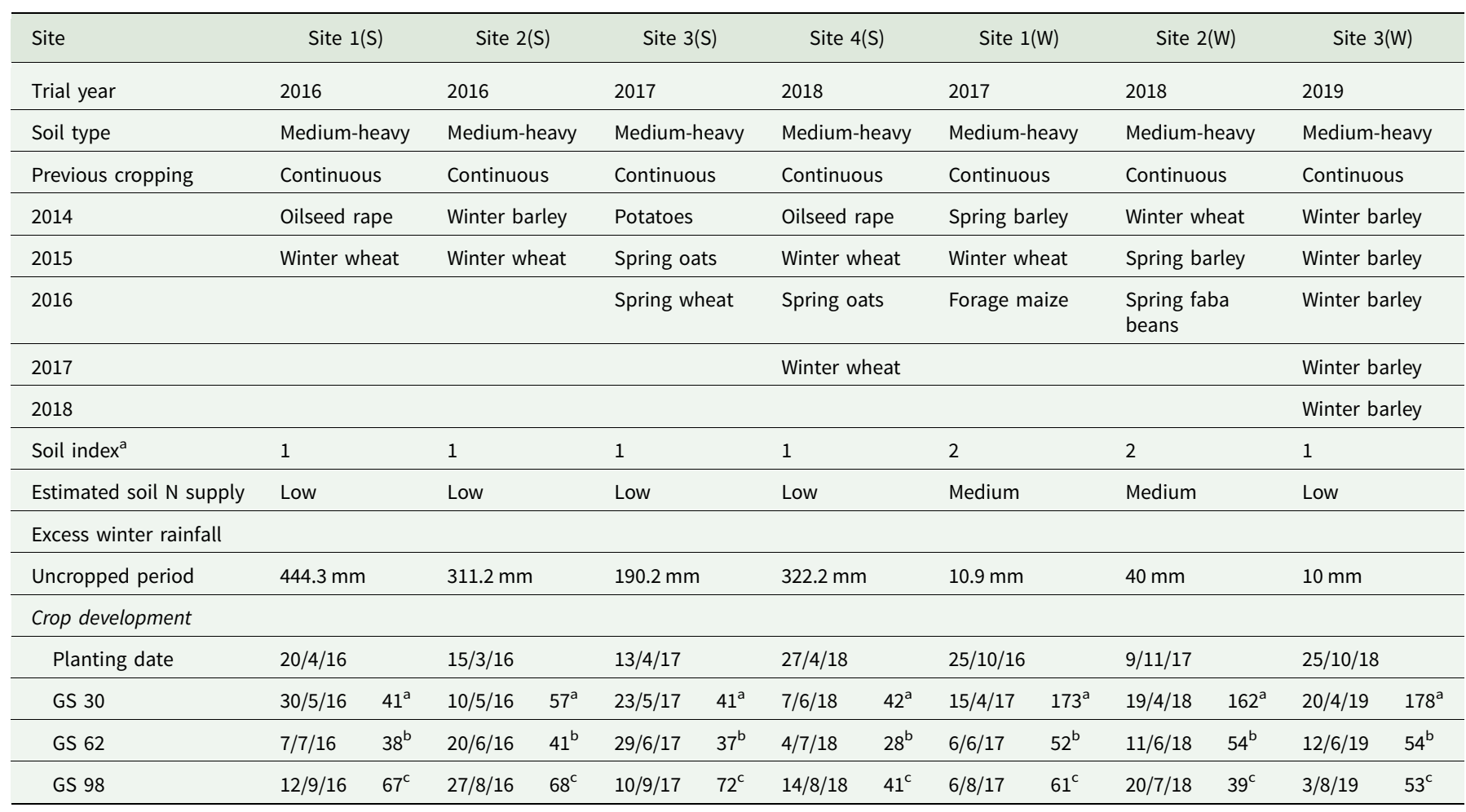

$\mathrm{GS}$, growth stage; $\mathrm{N}$, nitrogen.

${ }^{\mathrm{a}}$ Time in days from planting to GS 30

${ }^{\mathrm{b}}$ Time in days from GS 30 to GS 62 .

${ }^{\mathrm{c}}$ Time in days from GS 62 to GS 98 .

harvest, 15 panicles/plot were randomly selected for dissection of panicle components. After slow oven drying $\left(40^{\circ} \mathrm{C}\right)$ to a constant dry weight, spikelet number per panicle and aborted spikelets per panicle were counted. Primary, secondary and tertiary grains were threshed, identified, weighed and counted. Total grain/panicle was calculated along with the numbers of aborted primary and secondary grains. Tertiary grain number is presented as the $\%$ of grains per panicle, with all grain site abortion data presented as the mean value per 15 panicles. Panicle conformation measurements were not recorded at site $2(\mathrm{~S})$.

Plot yields were measured at full maturity using a Sampo Rosenlow 2025 plot combine (Pori, Finland), with an electronic weight cell. Where lodging occurred, harvesting was in the direction of lodging at slow speed to maximize grain recovery. TGW was calculated using a Contador seed counter (Pfeuffer Gmbh, Kitzingen, Germany). Grains $/ \mathrm{m}^{2}$ data were calculated from panicle number and grains/panicle.

\section{Statistical analysis}

Bartletts test of homogeneity was conducted separately on the spring and winter data sets and it was found that the data were not homogenous for any variable due to drought conditions at site $4(\mathrm{~S})$ and site $2(\mathrm{~W})$. Each experiment was therefore analysed 
Spring Sown Oats

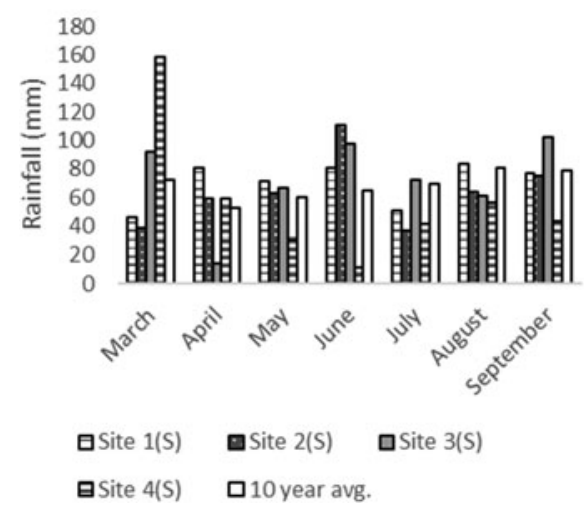

Spring Sown Oats

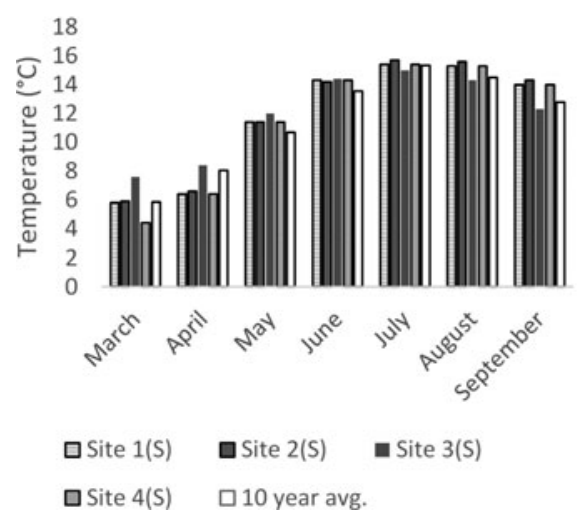

Winter Sown Oats

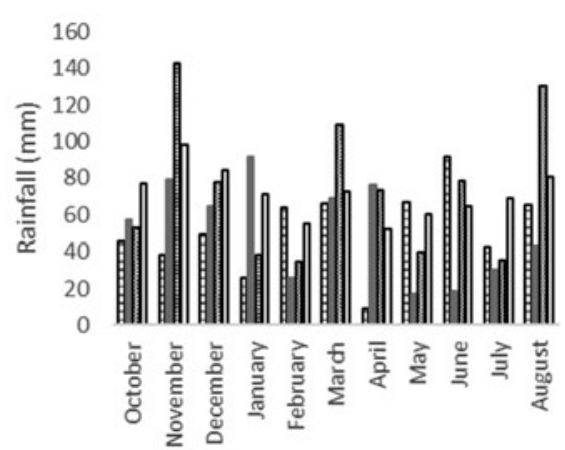

口Site $1(\mathrm{~W})$ घSite $2(\mathrm{~W}) \square$ Site $3(\mathrm{~W})$ 口10year avg.
Fig. 1. Monthly rainfall values $(\mathrm{mm})$ from March to September for spring-sown oats and October to August for winter-sown oats

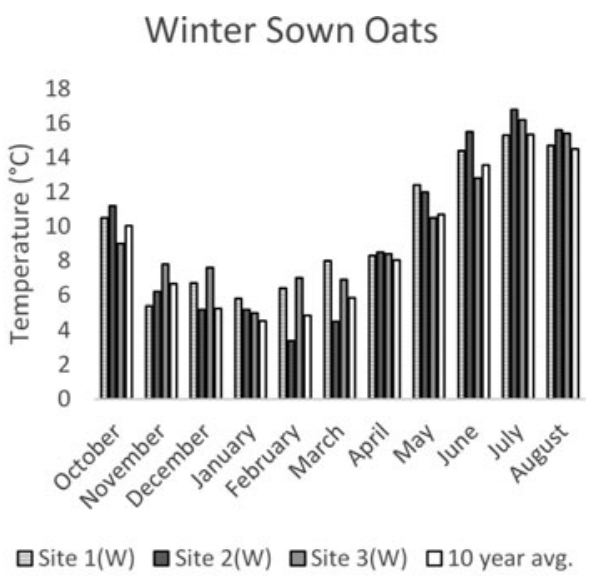

Fig. 2. Monthly rainfall values $(\mathrm{mm})$ from March to September for spring-sown oats and October to August for winter-sown oats individually for all variables. Analysis was performed using the PROC MIXED procedure of SAS 9.4. Seed rate, applied N rate and PGR application were included as fixed effects with replication effects considered random. The model used was

$$
\begin{aligned}
Y= & \mu+\operatorname{Block}(\text { Experiment }) k l+\text { Cultivar } m \\
& + \text { Seed Rate } n+\mathrm{N} \text { rate } o+\text { PGR application } p \\
& + \text { Om }, n\{m \ldots p\}+\operatorname{Pklm}\{m \ldots p\}+\text { Qmnop }
\end{aligned}
$$

where $Y$ is the observation, $\mu$ is the overall mean, $O, P$ and $Q$ represent all possible two-, three- and four-way interaction between the agronomic variables, respectively. The main effects of these factors are presented in a tabular form with the probability of interactions between these factors also presented. These interactions are not included in the tabular form due to inconsistency across seasons and experiments.

\section{Results}

\section{Climatic conditions}

Monthly and 10-year average rainfall and mean temperatures for the spring- and winter-sown experiments are presented in Figs 1 and 2. Rainfall levels were similar at spring-sown sites 1(S), 2(S) and $3(\mathrm{~S})$ whereas site $4(\mathrm{~S})$ (2018) experienced moisture stress due to the lack of summer precipitation. High levels of August rainfall led to significant lodging at sites $1(\mathrm{~S}), 2(\mathrm{~S})$ and $3(\mathrm{~S})$. Total rainfall levels were similar between site $1(\mathrm{~W})(2017)$ and site 2(W) (2018), but the pattern of rainfall varied greatly. Site $2(\mathrm{~W})$ had high levels of winter precipitation and a period of moisture stress during the summer. Site $3(\mathrm{~W})$ was a wet experimental site with high rainfall levels recorded throughout the season. The influence of temperature on crop development was also of importance, particularly in winter-sown experiments. Site 2(W) experienced a period of extreme cold in February and March relative to sites $1(\mathrm{~W})$ and $3(\mathrm{~W})$ where good temperatures encouraged higher early season growth. Temperature was relatively consistent across spring-sown experimental sites.

\section{Grain yield and yield components}

The effects of agronomic factors on grain yield, grains $/ \mathrm{m}^{2}$ and TGW are presented in Table 3 (spring-sown oats) and Table 4 (wintersown oats). Grain yield increases of $0.22-0.45 \mathrm{t} / \mathrm{ha}$ in the spring sowings and $0.4-0.8 \mathrm{t} / \mathrm{ha}$ in the winter sowings were observed as the seed rate increased from 250 to 450 seeds $/ \mathrm{m}^{2}$. Similar increases were observed in response to the increased levels of applied $\mathrm{N}$ in all experiments. For spring sowings, the major increases were observed between 40 and $100 \mathrm{~kg} \mathrm{~N} / \mathrm{ha}(0.7-1.5 \mathrm{t} / \mathrm{ha})$ with an increase of between 0.1 and $0.6 \mathrm{t} / \mathrm{ha}$ observed as the applied $\mathrm{N}$ rate increased from 100 to $160 \mathrm{~kg} \mathrm{~N} / \mathrm{ha}$. The response in winter-sown crops was $0.5-2.04 \mathrm{t} / \mathrm{ha}$ as the rate of applied $\mathrm{N}$ increased from 80 to $170 \mathrm{~kg}$ $\mathrm{N} /$ ha. The benefit of applying additional $\mathrm{N}$ above $130 \mathrm{~kg} \mathrm{~N} / \mathrm{ha}$ on spring-sown crops and $170 \mathrm{~kg} \mathrm{~N} / \mathrm{ha}$ on winter-sown crops was limited and site specific in nature. The application of PGR increased the grain yield at sites $2(\mathrm{~S}), 3(\mathrm{~S})$ and $4(\mathrm{~S})$. 
Table 3. Effect of agronomic factors on grain yield, grain number and TGW in spring-sown oats

\begin{tabular}{|c|c|c|c|c|c|c|c|c|c|c|c|c|c|}
\hline & \multirow[b]{2}{*}{ df } & \multicolumn{4}{|c|}{ Grain yield $(\mathrm{t} / \mathrm{ha})^{\mathrm{a}}$} & \multicolumn{4}{|c|}{ Grains $/ \mathrm{m}^{2} \mathrm{~b}$} & \multicolumn{4}{|c|}{$\mathrm{TGW}^{\mathrm{a}}$} \\
\hline & & Site $1(\mathrm{~S})$ & Site 2(S) & Site $3(\mathrm{~S})$ & Site $4(S)$ & Site $1(\mathrm{~S})$ & Site $2(\mathrm{~S})$ & Site 3(S) & Site $4(S)$ & Site $1(\mathrm{~S})$ & Site 2(S) & Site $3(\mathrm{~S})$ & Site $4(S)$ \\
\hline Seed rate & 2 & & & & & & & & & & & & \\
\hline 250 seeds $/ \mathrm{m}^{2}$ & & 8.13 & 6.95 & 7.07 & 4.58 & 21655 & 19119 & 20075 & 18131 & 37.9 & 37.1 & 35.3 & 32.1 \\
\hline 350 seeds $/ \mathrm{m}^{2}$ & & 8.22 & 7.20 & 7.39 & 4.78 & 21871 & 19275 & 21472 & 19229 & 37.8 & 37.3 & 34.6 & 33.0 \\
\hline 450 seeds $/ \mathrm{m}^{2}$ & & 8.48 & 7.33 & 7.27 & 4.92 & 22788 & 19912 & 20921 & 20061 & 37.4 & 37.2 & 34.9 & 32.2 \\
\hline LSD & & 0.24 & 0.26 & 0.23 & 0.14 & 841 & 679 & 748 & 555 & 0.75 & 0.54 & 1.45 & 0.70 \\
\hline$P$ & & $<0.05$ & $<0.05$ & $<0.05$ & $<0.001$ & $<0.05$ & $<0.05$ & $<0.01$ & $<0.001$ & n.s. & n.s. & n.s. & n.s. \\
\hline Applied N (kg N/ha) & 5 & & & & & & & & & & & & \\
\hline 40 & & 6.64 & 6.55 & 6.61 & 4.50 & 17050 & 17163 & 18391 & 18026 & 39.2 & 38.1 & 36.1 & 32.5 \\
\hline 70 & & 7.79 & 7.02 & 7.26 & 4.72 & 20302 & 18840 & 20137 & 18944 & 38.5 & 37.2 & 36.2 & 32.7 \\
\hline 100 & & 8.35 & 7.20 & 7.34 & 4.74 & 22093 & 19825 & 21674 & 19071 & 37.9 & 37.1 & 34.0 & 32.1 \\
\hline 130 & & 8.90 & 7.25 & 7.48 & 4.80 & 23927 & 20378 & 21623 & 18355 & 37.3 & 36.8 & 34.7 & 32.7 \\
\hline 160 & & 8.95 & 7.58 & 7.53 & 4.81 & 23938 & 20392 & 21753 & 19479 & 37.4 & 37.1 & 34.8 & 32.3 \\
\hline 190 & & 9.02 & 7.36 & 7.24 & 4.97 & 25319 & 20012 & 21360 & 20968 & 35.9 & 36.8 & 34.0 & 31.7 \\
\hline LSD & & 0.33 & 0.37 & 0.33 & 0.20 & 1190 & 961 & 1058 & 784 & 1.06 & 0.77 & 2.07 & 0.99 \\
\hline$P$ & & $<0.001$ & $<0.001$ & $<0.001$ & $<0.001$ & $<0.001$ & $<0.001$ & $<0.001$ & $<0.001$ & $<0.001$ & $<0.05$ & $<0.05$ & n.s. \\
\hline PGR application & 1 & & & & & & & & & & & & \\
\hline PGR- & & 8.27 & 6.99 & 7.06 & 4.67 & 21823 & 18897 & 20019 & 18883 & 38.1 & 37.4 & 35.4 & 32.7 \\
\hline PGR+ & & 8.28 & 7.33 & 7.42 & 4.85 & 22387 & 19973 & 21627 & 19397 & 37.3 & 36.9 & 34.5 & 32.0 \\
\hline LSD & & 0.19 & 0.22 & 0.19 & 0.11 & 687 & 554 & 610 & 453 & 0.61 & 0.44 & 1.18 & 0.57 \\
\hline$P$ & & n.s. & $<0.01$ & $<0.001$ & $<0.01$ & n.s. & $<0.001$ & $<0.001$ & n.s. & $<0.05$ & $<0.05$ & n.s. & $<0.05$ \\
\hline \multicolumn{14}{|l|}{ Interactions } \\
\hline $\mathrm{SR} \times \mathrm{N}$ & 10 & n.s. & n.s. & n.s. & n.s. & n.s. & $<0.01$ & n.s. & n.s. & n.s. & n.s. & n.s. & n.s. \\
\hline $\mathrm{SR} \times \mathrm{PGR}$ & 2 & n.s. & n.s. & n.s. & n.s. & n.s. & $<0.001$ & n.s. & n.s. & n.s. & $<0.05$ & n.s. & $<0.05$ \\
\hline $\mathrm{N} \times \mathrm{PGR}$ & 5 & n.s. & $<0.05$ & $<0.05$ & n.s. & n.s. & n.s. & n.s. & n.s. & n.s. & n.s. & n.s. & n.s. \\
\hline$S R \times N \times P G R$ & 10 & n.s. & n.s. & n.s. & n.s. & n.s. & n.s. & n.s. & n.s. & n.s. & n.s. & n.s. & n.s. \\
\hline
\end{tabular}

n.s., not significant; $N$, nitrogen; $P G R$, plant growth regulator; SR, seed rate.

Whole plot combine data.

${ }^{\mathrm{b}}$ Calculated from yield and TGW data. 
Table 4. Effects of agronomic factors on grain yield, grains $/ \mathrm{m}^{2}$ and $\mathrm{TGW}$ of winter-sown oat

\begin{tabular}{|c|c|c|c|c|c|c|c|c|c|c|}
\hline & \multirow[b]{2}{*}{ df } & \multicolumn{3}{|c|}{ Grain yield $(\mathrm{t} / \mathrm{ha})^{\mathrm{a}}$} & \multicolumn{3}{|c|}{ Grains $/ \mathrm{m}^{2} \mathrm{~b}$} & \multicolumn{3}{|c|}{$\mathrm{TGW}^{\mathrm{a}}$} \\
\hline & & Site $1(W)$ & Site $2(W)$ & Site $3(W)$ & Site $1(W)$ & Site $2(W)$ & Site $3(W)$ & Site $1(W)$ & Site $2(W)$ & Site $3(W)$ \\
\hline Seed rate & 2 & & & & & & & & & \\
\hline 250 seeds $/ \mathrm{m}^{2}$ & & 10.26 & 8.31 & 8.26 & 27604 & 25629 & 20696 & 37.3 & 32.4 & 40.1 \\
\hline 350 seeds $/ \mathrm{m}^{2}$ & & 10.26 & 8.80 & 8.55 & 27973 & 26869 & 21250 & 36.8 & 32.9 & 40.2 \\
\hline 450 seeds $/ \mathrm{m}^{2}$ & & 10.71 & 9.12 & 8.97 & 29476 & 27884 & 22670 & 35.9 & 32.5 & 39.6 \\
\hline LSD & & 0.322 & 0.403 & 0.373 & 1292.7 & 1164.9 & 1012.7 & 1.18 & 1.00 & 0.80 \\
\hline$P$ & & $<0.01$ & $<0.001$ & $<0.001$ & $<0.05$ & $<0.001$ & $<0.001$ & n.s. & n.s. & n.s. \\
\hline Applied N (kg N/ha) & 4 & & & & & & & & & \\
\hline 80 & & - & 8.03 & 6.87 & - & 24285 & 17730 & - & 33.3 & 39.9 \\
\hline 110 & & 10.08 & 8.54 & 7.91 & 27015 & 25667 & 19504 & 36.8 & 33.3 & 40.6 \\
\hline 140 & & 10.42 & 8.82 & 8.73 & 28421 & 27150 & 21657 & 36.8 & 32.5 & 40.2 \\
\hline 170 & & 10.50 & 9.11 & 9.71 & 29171 & 28443 & 23934 & 36.1 & 31.8 & 40.4 \\
\hline 200 & & 10.65 & 9.22 & 9.75 & 28797 & 28426 & 24866 & 37.0 & 32.2 & 38.7 \\
\hline LSD & & 0.372 & 0.570 & 0.482 & 1480.0 & 1503.9 & 1307.4 & 1.36 & 1.28 & 1.04 \\
\hline$P$ & & $<0.05$ & $<0.001$ & $<0.001$ & $<0.05$ & $<0.001$ & $<0.001$ & n.s. & n.s. & $<0.01$ \\
\hline \multicolumn{11}{|l|}{ Interactions } \\
\hline $\mathrm{SR} \times \mathrm{N}$ & 8 & n.s. & n.s. & n.s. & n.s. & n.s. & n.s. & n.s. & n.s. & n.s. \\
\hline
\end{tabular}

n.s., not significant; $\mathrm{N}$, nitrogen; $\mathrm{SR}$, seed rate.

ahole plot combine data.

${ }^{\mathrm{b}}$ Calculated from yield and TGW data.

Grains $/ \mathrm{m}^{2}$ increased in all crops as both seed rate and applied $\mathrm{N}$ rate were increased. Increases of between 1000 and 2000 grains/ $\mathrm{m}^{2}$ as seed rate increased in spring-sowings, with increases of 2000-2500 grains $/ \mathrm{m}^{2}$ observed for winter sown. Increases following spring sowing, from 40 to $130 \mathrm{~kg} \mathrm{~N} / \mathrm{ha}$, were in the range of $3000-7000$ grains $/ \mathrm{m}^{2}$ with the additional increases beyond this point site-specific and in the range of $0-1000$ grains $/ \mathrm{m}^{2}$. A similar range was observed for winter sown, with increases of 3000 to 5000 grains $/ \mathrm{m}^{2}$ over the range of 80 to $200 \mathrm{~kg} \mathrm{~N} / \mathrm{ha}$ of applied $\mathrm{N}$.

Increasing the seed rate had no effect on TGW in spring- or winter-sown oats. Increasing the level of applied $\mathrm{N}$ had a negative effect on TGW in all spring-sown crops and at site $3(\mathrm{~W})$. The application of PGR also had a negative effect on TGW in all spring-sown crops.

The effects of agronomic factors on spikelet number per panicle, grains/panicle and panicles $/ \mathrm{m}^{2}$ are presented in Table 5 (spring-sown oats) and Table 6 (winter-sown oats). There was a small reduction observed in spikelets/panicle in response to the increased seed rate at sites $1(\mathrm{~S}), 4(\mathrm{~S})$ and $2(\mathrm{~W})$. Spikelet number per panicle increased in response to higher levels of the applied $\mathrm{N}$ at sites $1(\mathrm{~S})$ and $3(\mathrm{~W})$ but no consistent trends were observed across all the experimental sites. Spikelet number per panicle was higher in winter-sown oats.

Grains/panicle were negatively impacted by the increased seed rate at sites $3(\mathrm{~S}), 4(\mathrm{~S}), 1(\mathrm{~W})$ and $2(\mathrm{~W})$. Increased levels of applied $\mathrm{N}$ rate resulted in significant increases in grains/panicle at sites 1 (S) and $3(\mathrm{~W})$ with the application of PGR increasing grains/panicle at site 3(S). Winter-sown oats produced higher numbers of grains/panicle.

Panicles $/ \mathrm{m}^{2}$ linearly increased with the increased seed rate in all spring- and winter-sown crops. Increases in spring sowings were in the range of 39-72 panicles $/ \mathrm{m}^{2}$ with increases of $30-55$ panicles $/ \mathrm{m}^{2}$ observed in winter sowings. Significant increases were noted in response to the increased applied $\mathrm{N}$ rate observed at all experimental sites. Panicle number increases in spring sowings were most profound between 40 and $130 \mathrm{~kg} \mathrm{~N} / \mathrm{ha}$ and were in the range of 60-150 panicles $/ \mathrm{m}^{2}$ excluding the site which experienced prolonged drought. Increasing the rate of applied $\mathrm{N}$ from 130 to $190 \mathrm{~kg} \mathrm{~N} / \mathrm{ha}$ resulted in increases of 21-24 panicles $/ \mathrm{m}^{2}$. Increases in winter-sown oats were notably site specific. Increases of 16-35 panicles $/ \mathrm{m}^{2}$ were observed as the rate of applied $\mathrm{N}$ increased from 80 to $140 \mathrm{~kg} \mathrm{~N} / \mathrm{ha}$ at sites $1(\mathrm{~W})$ and $2(\mathrm{~W})$ with increases of 92 panicles $/ \mathrm{m}^{2}$ observed as the applied $\mathrm{N}$ rate increased from 80 to $200 \mathrm{~kg}$ $\mathrm{N} / \mathrm{ha}$ at site $3(\mathrm{~W})$. The application of PGR had no effect on panicle number in any spring-sown crop.

\section{Panicle conformation}

\section{Proportion of primary grain weight}

The effects of agronomic factors on the proportion of primary grain weight and number and $\%$ of tertiary grains per panicle is presented in Table 7 (spring-sown oats) and Table 8 (winter-sown oats). Agronomic effects on the proportion of primary grain weight were not generally significant in spring- or winter-sown oats. However, increases in the proportion of primary grain weight were observed in response to the applied $\mathrm{N}$ rate at site $3(\mathrm{~S})$ with an increase observed at site $3(\mathrm{~W})$ as the seed rate increased.

\section{Proportion of primary grain number}

Overall, the seed rate had no consistent effect on the proportion of primary grain number in spring-sown oats. Significant contrasting responses were observed in winter-sown oats, with a reduction 
Table 5. Effects of agronomic factors on spikelets/panicle, grains/panicle and panicles $/ \mathrm{m}^{2}$ of spring-sown oats

\begin{tabular}{|c|c|c|c|c|c|c|c|c|c|c|c|c|c|}
\hline & \multirow[b]{2}{*}{ df } & \multicolumn{4}{|c|}{ Spikelets/panicle ${ }^{a}$} & \multicolumn{4}{|c|}{ Grains/panicle ${ }^{a}$} & \multicolumn{4}{|c|}{ Panicles $/ \mathrm{m}^{2} \mathrm{~b}$} \\
\hline & & Site $1(\mathrm{~S})$ & Site $2(\mathrm{~S})$ & Site 3(S) & Site $4(S)$ & Site $1(\mathrm{~S})$ & Site $2(\mathrm{~S})$ & Site $3(\mathrm{~S})$ & Site $4(S)$ & Site $1(\mathrm{~S})$ & Site $2(\mathrm{~S})$ & Site $3(\mathrm{~S})$ & Site $4(S)$ \\
\hline Seed rate & 2 & & & & & & & & & & & & \\
\hline 250 seeds $/ \mathrm{m}^{2}$ & & 37.7 & - & 28.2 & 33.1 & 69.8 & - & 56.8 & 60.6 & 395.5 & 398.6 & 480.6 & 307.2 \\
\hline 350 seeds $/ \mathrm{m}^{2}$ & & 35.8 & - & 28.8 & 32.0 & 68.7 & - & 53.6 & 58.7 & 405.2 & 435.1 & 529.0 & 329.9 \\
\hline 450 seeds $/ \mathrm{m}^{2}$ & & 37.7 & - & 27.9 & 29.9 & 69.9 & - & 49.6 & 54.2 & 441.6 & 445.4 & 535.4 & 379.1 \\
\hline LSD & & 1.52 & - & 1.59 & 1.38 & 3.10 & - & 3.72 & 2.53 & 17.56 & 16.10 & 18.49 & 10.00 \\
\hline$P$ & & $<0.05$ & - & n.s. & $<0.001$ & n.s. & - & $<0.001$ & $<0.001$ & $<0.001$ & $<0.001$ & $<0.001$ & $<0.001$ \\
\hline Applied N (kg N/ha) & 5 & & & & & & & & & & & & \\
\hline 40 & & 35.1 & - & 28.5 & 31.0 & 66.5 & - & 56.4 & 56.3 & 328.6 & 373.8 & 411.2 & 327.1 \\
\hline 70 & & 35.9 & - & 28.9 & 31.3 & 67.7 & - & 53.1 & 57.9 & 375.0 & 422.7 & 451.9 & 331.3 \\
\hline 100 & & 35.8 & - & 27.0 & 30.7 & 67.4 & - & 52.6 & 56.9 & 399.5 & 433.8 & 499.0 & 340.9 \\
\hline 130 & & 37.7 & - & 28.8 & 31.9 & 69.7 & - & 52.7 & 56.9 & 443.3 & 433.9 & 560.7 & 340.2 \\
\hline 160 & & 39.7 & - & 28.2 & 32.2 & 74.7 & - & 53.8 & 58.2 & 459.6 & 439.6 & 582.8 & 342.8 \\
\hline 190 & & 37.9 & - & 28.4 & 32.9 & 70.9 & - & 51.5 & 60.8 & 478.8 & 454.4 & 584.4 & 350.1 \\
\hline LSD & & 2.15 & - & 2.25 & 1.95 & 4.42 & - & 5.24 & 3.58 & 24.83 & 22.83 & 26.15 & 14.15 \\
\hline$P$ & & $<0.001$ & - & n.s. & n.s. & $<0.01$ & - & n.s. & n.s. & $<0.001$ & $<0.001$ & $<0.001$ & $<0.05$ \\
\hline PGR application & 1 & & & & & & & & & & & & \\
\hline PGR- & & 37.1 & - & 28.1 & 31.3 & 69.0 & - & 50.6 & 57.3 & 409.4 & 429.9 & 510.0 & 334.8 \\
\hline PGR+ & & 37.0 & - & 28.5 & 32.0 & 69.9 & - & 56.5 & 58.3 & 418.8 & 422.8 & 519.9 & 342.6 \\
\hline LSD & & 1.24 & - & 1.29 & 1.13 & 2.52 & - & 3.03 & 2.07 & 14.33 & 13.15 & 15.10 & 8.17 \\
\hline$P$ & & n.s. & - & n.s. & n.s. & n.s. & - & $<0.001$ & n.s. & n.s. & n.s. & n.s. & n.s. \\
\hline \multicolumn{14}{|l|}{ Interactions } \\
\hline $\mathrm{SR} \times \mathrm{N}$ & 10 & n.s. & - & n.s. & n.s. & n.s. & - & n.s. & n.s. & n.s. & n.s. & n.s. & n.s. \\
\hline $\mathrm{SR} \times \mathrm{PGR}$ & 2 & n.s. & - . & n.s. & n.s. & n.s. & - & n.s. & n.s. & n.s. & n.s. & $<0.001$ & $<0.05$ \\
\hline $\mathrm{N} \times \mathrm{PGR}$ & 5 & $<0.05$ & - & n.s. & n.s. & n.s. & - & n.s. & n.s. & n.s. & n.s. & n.s. & n.s. \\
\hline$S R \times N \times P G R$ & 10 & n.s. & - & n.s. & n.s. & - & - & n.s. & n.s. & n.s. & n.s. & n.s. & n.s. \\
\hline
\end{tabular}

n.s., not significant; $N$, nitrogen; $\mathrm{SR}$, seed rate; $\mathrm{PGR}$, plant growth regulator. aMean value per panicle from 15 panicles per plot.

Field plot observation. 
Table 6. Effect of agronomic factors on spikelets/panicle, grains/panicle and panicles $/ \mathrm{m}^{2}$ of winter-sown oats

\begin{tabular}{|c|c|c|c|c|c|c|c|c|c|c|}
\hline & \multirow[b]{2}{*}{ df } & \multicolumn{3}{|c|}{ Spikelets/panicle ${ }^{a}$} & \multicolumn{3}{|c|}{ Grains/panicle $^{a}$} & \multicolumn{3}{|c|}{ Panicles $/ \mathrm{m}^{2} \mathrm{~b}$} \\
\hline & & Site $1(W)$ & Site $2(W)$ & Site $3(W)$ & Site $1(W)$ & Site $2(W)$ & Site $3(W)$ & Site $1(W)$ & Site $2(\mathrm{~W})$ & Site $3(W)$ \\
\hline Seed rate & 2 & & & & & & & & & \\
\hline 250 seeds $/ \mathrm{m}^{2}$ & & 43.7 & 75.4 & 73.9 & 121.4 & 159.3 & 134.8 & 287.5 & 402.9 & 303.6 \\
\hline 350 seeds $/ \mathrm{m}^{2}$ & & 44.4 & 72.4 & 73.5 & 124.5 & 156.0 & 125.8 & 280.1 & 423.6 & 328.9 \\
\hline 450 seeds $/ \mathrm{m}^{2}$ & & 39.1 & 70.6 & 74.7 & 99.93 & 141.7 & 129.0 & 317.0 & 459.2 & 358.8 \\
\hline LSD & & 5.01 & 3.65 & 6.88 & 16.55 & 10.21 & 13.42 & 13.02 & 25.98 & 22.26 \\
\hline$P$ & & n.s. & $<0.05$ & n.s. & $<0.01$ & $<0.01$ & n.s. & $<0.001$ & $<0.001$ & $<0.001$ \\
\hline Applied N (kg N/ha) & 4 & & & & & & & & & \\
\hline 80 & & - & 69.8 & 67.3 & - & 146.6 & 112.5 & 287.2 & 394.0 & 282.5 \\
\hline 110 & & 40.9 & 70.8 & 69.6 & 114.0 & 148.0 & 124.2 & 302.3 & 421.8 & 316.5 \\
\hline 140 & & 43.0 & 74.8 & 78.0 & 118.8 & 154.0 & 137.9 & 287.0 & 439.0 & 319.5 \\
\hline 170 & & 42.2 & 74.7 & 77.3 & 114.5 & 157.0 & 133.3 & 302.9 & 444.5 & 359.3 \\
\hline 200 & & 43.4 & 73.9 & 78.1 & 113.9 & 155.9 & 141.5 & 287.2 & 443.5 & 374.3 \\
\hline LSD & & 5.80 & 4.71 & 8.88 & 18.96 & 13.18 & 17.33 & 14.91 & 33.53 & 28.74 \\
\hline$P$ & & n.s. & n.s. & $<0.05$ & n.s. & n.s. & $<0.05$ & $<0.05$ & $<0.05$ & $<0.001$ \\
\hline \multicolumn{11}{|l|}{ Interactions } \\
\hline $\mathrm{SR} \times \mathrm{N}$ & 8 & n.s. & n.s. & n.s. & n.s. & n.s. & n.s. & n.s. & n.s. & n.s. \\
\hline
\end{tabular}

n.s., not significant; $\mathrm{N}$, nitrogen; SR, seed rate.

${ }^{\mathrm{a}}$ Mean value per panicle from 15 panicles per plot.

${ }^{\mathrm{b}}$ Field plot observation.

observed at site $2(\mathrm{~W})$ and an increase at site $3(\mathrm{~W})$. Increasing the rate of applied $\mathrm{N}$ resulted in an increase in the proportion of primary grain number at sites $1(\mathrm{~S}), 3(\mathrm{~S})$ and $1(\mathrm{~W})$. The application of PGR reduced the proportion of primary grains by number only at site $1(\mathrm{~S})$, and not in any other crop.

\section{Tertiary grains}

The $\%$ grains accounted by tertiary grains reduced as the seed rate increased at site $4(\mathrm{~S})$ with no seed rate effects observed in any other experiment. Increasing the rate of applied $\mathrm{N}$ resulted in an increase in tertiary grains at site $3(\mathrm{~W})$ and not at any other site. The application of PGR had no effect on tertiary grain number at any spring-sown site.

\section{Aborted grain sites}

The effects of agronomic factors on the number of aborted spikelets, primary grain and secondary grain sites are presented (Table 9, spring-sown oats; Table 10, winter-sown oats). Grain site abortion was reduced as the seed rate increased at site $3(\mathrm{~S})$ with the number of aborted secondary grain sites reduced at site $4(\mathrm{~S})$. There were interesting although insignificant increases in aborted primary and secondary grain sites as the seed rate increased at site $3(\mathrm{~W})$. Increasing the rate of applied $\mathrm{N}$ reduced spikelet abortion at site $3(\mathrm{~S})$ with an increase observed at site 3 (W). Increases in the applied $\mathrm{N}$ rate also reduced the levels of primary and secondary grain site abortion at site $3(\mathrm{~W})$. The application of PGR increased the level of aborted secondary grain sites at site 3(S) but this was not repeated in any other crop.

\section{Key correlations}

The correlation data presented in Tables 11 and 12 provide a unique, novel insight into the complex and site-specific nature of grain site abortion and its role in the maintenance of grain yield in oats. Secondary grain site abortion was significantly associated $(P<0.05)$ with the proportion of primary grain weight and number at sites $1(S)$ and $3(S)(r=0.17-0.25)$ indicating that a high rate of secondary grain site abortion occurred within treatments where primary grain sites were dominant. Observations from winter-sown sites also suggest that grain fill within spikelets is strongly related to assimilate availability during grain fill. At site $1(\mathrm{~W})$ which was very high yielding (9.5-11 t/ha), secondary grain site abortion was negatively correlated with grain yield $(r=-0.41)$ with a similar correlation observed at site $3(\mathrm{~W})(r=-0.27)$. These correlations indicate that a higher level of secondary grains was formed at these higher yield levels. At site 2(W) aborted primary grain number was significantly associated with grain yield $(r=0.22)$, primary grain weight ratio $(r=0.22)$ and TGW $(r=0.23)$. This experiment was characterized by a prolonged drought period during grain fill and primary grains were aborted by the plant to ensure a sustainable amount of grain fill within remaining grain sites. At site $1(S)$ the yield was significantly associated $(P<0.05)$ with secondary grain site abortion indicating that remobilization of assimilates occurred from secondary grain sites into primary grain sites in order to maintain grain yield. The implications of these observations are two-fold. Firstly, the relationship between aborted secondary grains and primary grain weight and number ratios at spring-sown experiments indicates that assimilate supply was insufficient during grain fill and suggests that yield was source 
Table 7. Effect of agronomic factors on the proportion of primary grain weight and number and tertiary grain number in spring-sown oats

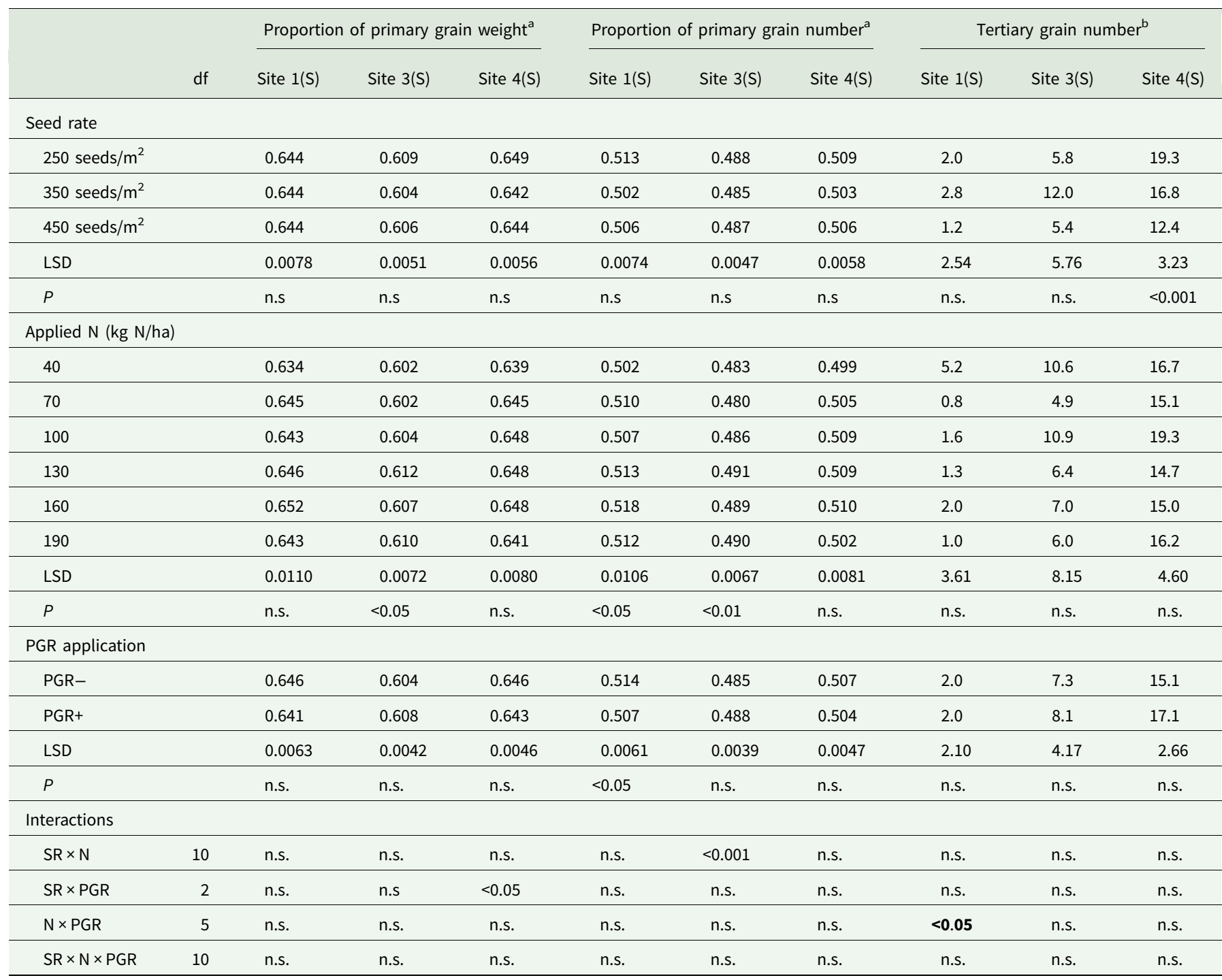

n.s., not significant; $N$, nitrogen; SR, seed rate; PGR, plant growth regulator.

aalues represent mean of 15 panicles.

balues represent \% of total grains.

limited in these experiments. The high level of secondary grains observed at high grain yield levels at sites $1(\mathrm{~W})$ and $3(\mathrm{~W})$ suggests that yield was sink limited at this site. There is a level of complexity to these responses, linked to the length and climatic suitability of the grain-fill period. Secondly, this points to a phenomenon within spikelets that primary grains are prioritized by oat plants during periods of assimilate shortages.

\section{Discussion}

The results of this study has shown that seed rate, PGR application and applied $\mathrm{N}$ fertilizer rate influence yield formation in spring- and winter-sown oat crops, although the responses were not always consistent across all crops or sowing times, which creates complexity in interpreting the observations. Overall, crop structure and yield formation processes were predominantly determined by applied $\mathrm{N}$ rate with seed rate and PGR application displaying minor effects.

\section{Yield components}

Winter-sown oat crops yielded higher and more consistently than spring-sown crops with maximum yields of $9-10$ and 5-9t/ha, respectively. Winter-sown crops were characterized by higher spikelet and grain numbers per panicle than in the spring sowings. Although a direct comparison is not possible due to separate experimental sites/years the increase in yield potential in wintersown oats is notable. The key determinant of yield potential in oats is grain number $/ \mathrm{m}^{2}$ (Peltonen-Sainio et al., 2007) with spikelet number per panicle in winter-sown oats increased due to the shortening of daylength and reduction in temperature during the winter period (Wall and Cartwright, 1976). This slows down crop development and leads to an increase in spikelet primordia development and in yield potential (Kirby and Appleyard, 1984). In contrast, spring-sown crops develop rapidly as daylength increases in the spring, reducing the duration and rate of apex development leading to a lower spikelet number per panicle. This reduction in preformed yield potential was a key contributor 
Table 8. Effects of agronomic factors on the proportion of primary grain weight and number and tertiary grain number in winter-sown oats

\begin{tabular}{|c|c|c|c|c|c|c|c|c|c|c|}
\hline & \multirow[b]{2}{*}{$\mathrm{df}$} & \multicolumn{3}{|c|}{ Proportion of primary grain weight ${ }^{a}$} & \multicolumn{3}{|c|}{ Proportion of primary grain number ${ }^{a}$} & \multicolumn{3}{|c|}{ Tertiary grain number ${ }^{\mathrm{b}}$} \\
\hline & & Site $1(W)$ & Site $2(W)$ & Site $3(W)$ & Site $1(W)$ & Site $2(\mathrm{~W})$ & Site $3(W)$ & Site $1(W)$ & Site $2(W)$ & Site $3(W)$ \\
\hline Seed rate & 2 & & & & & & & & & \\
\hline 250 seeds $/ \mathrm{m}^{2}$ & & 0.636 & 0.655 & 0.623 & 0.504 & 0.519 & 0.513 & - & 0.03 & 3.5 \\
\hline 350 seeds $/ \mathrm{m}^{2}$ & & 0.650 & 0.653 & 0.637 & 0.514 & 0.512 & 0.526 & - & 0.04 & 1.6 \\
\hline 450 seeds $/ \mathrm{m}^{2}$ & & 0.640 & 0.651 & 0.635 & 0.505 & 0.508 & 0.524 & - & 0.06 & 2.3 \\
\hline LSD & & 0.0140 & 0.0090 & 0.0060 & 0.0130 & 0.0085 & 0.0057 & - & 0.25 & 2.64 \\
\hline$P$ & & n.s. & n.s. & $<0.001$ & n.s. & $<0.05$ & $<0.001$ & - & n.s. & n.s. \\
\hline Applied $\mathrm{N}$ rate (kg N/ha) & 4 & & & & & & & & & \\
\hline 80 & & - & 0.654 & 0.636 & - & 0.517 & 0.523 & - & 0.2 & 0.8 \\
\hline 110 & & 0.638 & 0.648 & 0.633 & 0.500 & 0.505 & 0.521 & - & 0.3 & 1.4 \\
\hline 140 & & 0.635 & 0.658 & 0.629 & 0.501 & 0.518 & 0.520 & - & 0.2 & 0.7 \\
\hline 170 & & 0.650 & 0.654 & 0.631 & 0.518 & 0.516 & 0.520 & - & 0.03 & 3.2 \\
\hline 200 & & 0.644 & 0.650 & 0.630 & 0.511 & 0.510 & 0.521 & - & 0.03 & 6.2 \\
\hline LSD & & 0.0160 & 0.0122 & 0.0077 & 0.0145 & 0.0110 & 0.0074 & - & 0.40 & 3.42 \\
\hline$P$ & & n.s. & n.s. & n.s. & $<0.05$ & n.s. & n.s. & - & n.s. & $<0.01$ \\
\hline \multicolumn{11}{|l|}{ Interactions } \\
\hline $\mathrm{SR} \times \mathrm{N}$ & 8 & n.s. & n.s. & n.s. & n.s. & n.s. & n.s. & n.s. & n.s. & n.s. \\
\hline
\end{tabular}

n.s., not significant; $\mathrm{N}$, nitrogen; SR, seed rate.

${ }^{a}$ Values represent mean of 15 panicles.

balue represent \% of total grains.

to the observed lower yield response to applied $\mathrm{N}$ in the springsown crops.

The increases observed in panicles $/ \mathrm{m}^{2}$ were in line with those reported by Peltonen-Sainio and Jarvinen (1995) and Finnan et al. $(2019 a, b)$ with associated increases also observed in grains $/ \mathrm{m}^{2}$. Winter sowing of spring cultivars can be expected to result in some level of plant death resulting in lower plants $/ \mathrm{m}^{2}$. The wider range of observed increases in winter-sown experiments is therefore attributable to plant populations which are closer to or within the optimum range. Interestingly, the TGW of oats was relatively stable in response to seed rate when compared with the other key yield determining components, which is in line with Finnan et al. $(2019 a, b)$. It appears that increasing the seed rate within a narrow range has a slight positive effect on total sink capacity, depending on the amount of tiller production, but has a major effect on the components of sink capacity, namely panicles $/ \mathrm{m}^{2}$ and grains/panicle. As panicles $/ \mathrm{m}^{2}$ increase in response to increased seed rate, grains/panicle decrease. However, individual grain weight is not as elastic and remains consistent in comparison within a normal plant population range as suggested by Sadras (2007) and Finnan et al. (2019a, $b)$. Despite this, the study shows that yield increases of $0.22-0.45 \mathrm{t} / \mathrm{ha}$ were achievable in the spring sowings and $0.4-0.8 \mathrm{t} / \mathrm{ha}$ in the winter sowings. The benefits of using a high seed rate were linked to increases in both panicles $/ \mathrm{m}^{2}$ and a reduction in the proportion of tiller ears in the crop. This is beneficial as panicles from tillers have been shown to have smaller grains and lower grains/panicle than mainstem ears (Peltonen-sainio and Jarvinen, 1995; Finnan et al., 2019a, b). In addition, apical dominance will lead to the mainstem benefiting from the remobilization of assimilates contained in tiller ears which are aborted prior to anthesis (Palta et al., 1994).

Increasing the applied $\mathrm{N}$ rate resulted in increases in grains $/ \mathrm{m}^{2}$ in all crops. Interestingly, these increases were always attributable to increased panicles $/ \mathrm{m}^{2}$ rather than grains/panicle, which only increased at two sites in response to higher $\mathrm{N}$ fertilizer. A number of previous studies have also reported increases in ears $/ \mathrm{m}^{2}$ and grains/panicle in response to applied $\mathrm{N}$ rate, in winter wheat (Ellen and Spiertz, 1980, Efretui et al., 2016), spring barley (Easson, 1984; Baethgen et al., 1995) and oats (Browne et al., 2006; Finnan et al., 2019a). However, increases in grains/panicle and grain yield in response to $\mathrm{N}$ fertilizer application have also been reported previously in oats (Brinkman and Rho, 1984; Pecio and Bichonski, 2010; Finnan et al., 2019a), indicating an underlying complexity in this yield to sink relationship in oats. It is suggested by Hay and Walker (1989) that grain weight is a factor of a source-sink relationship, particularly regarding total grain density and environmental stresses during grain fill. Grain sites will then compete for assimilates, resulting in lower individual grain weights. There is also a non-competitive theory (Miralles and Slafer, 2007) that at higher grain numbers potential grain size is reduced as smaller grain sites are produced within spikelets. In oats, this would be linked to an increased detection of secondary and tertiary grain sites. The modern cultivars used in this study had high grain numbers but still produced TGW values in a consistent range suggesting that competition for assimilates is unlikely, particularly as crop growth rates have not improved in modern cultivars (Lynch and Frey, 1993). It has been hypothesized by Calderini et al. (1997) that modern cultivars have a higher ability to allocate assimilates to grain sites during grain 
Table 9. Effect of agronomic factors on post-anthesis grain site abortion in spring-sown oats

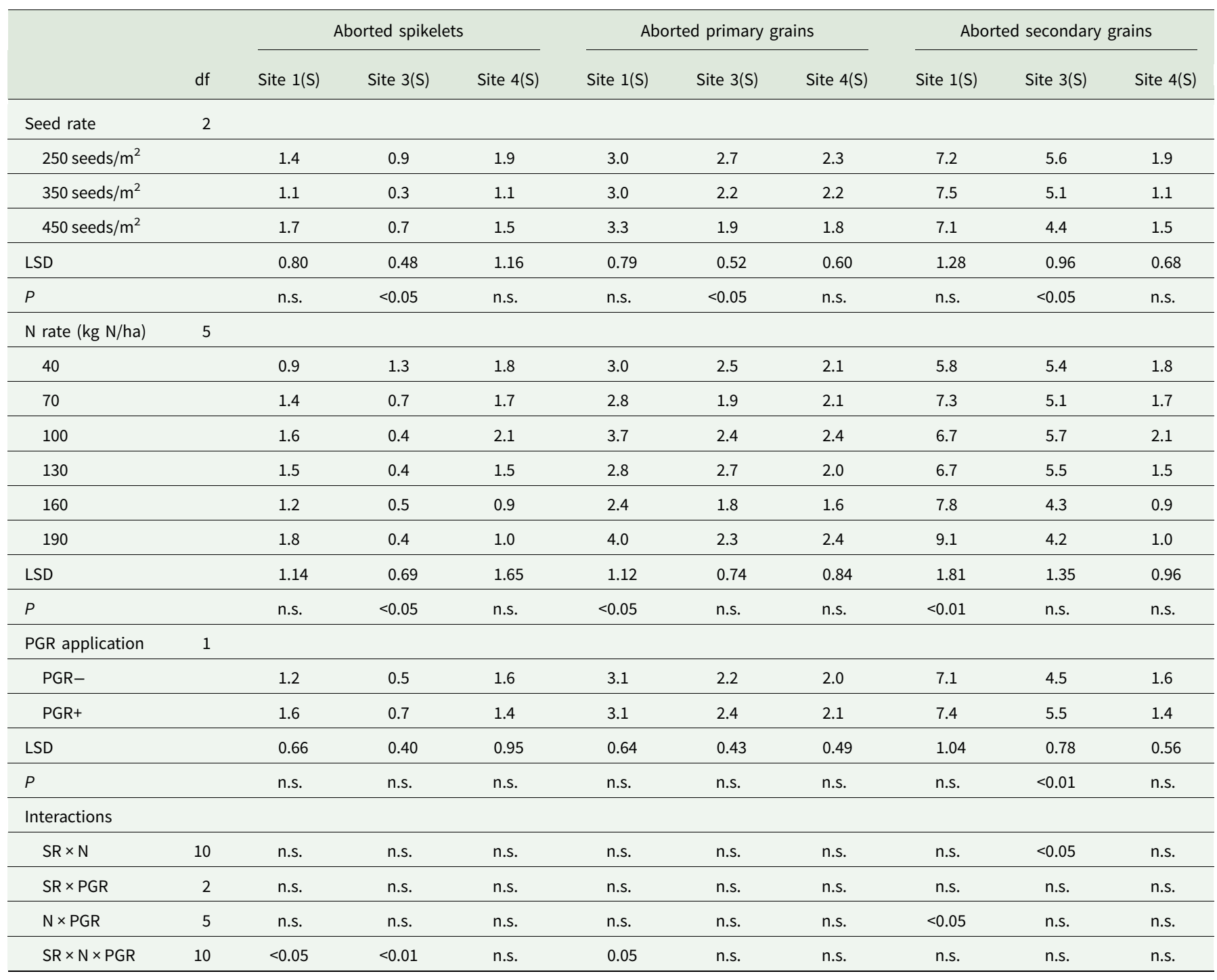

n.s., not significant; $\mathrm{N}$, nitrogen; SR, seed rate; PGR, plant growth regulator.

Values represent total number aborted grain sites per 15 panicles.

fill. Grain weight reductions at high grain numbers in oat are therefore linked to both reductions in potential grain size and competition for assimilates at high grain numbers. Therefore, applied $\mathrm{N}$ fertilizer has a crucial role in increasing the grain yield of oats highlighted by the positive effect it had on grain number. However, the effect of applied $\mathrm{N}$ fertilizer on grain weight is an interesting phenomenon and demonstrates a biological trade-off from a yield formation perspective. Finnan and Spink (2017) note that a yield maximization approach focused on the production of high grain numbers in oat will result in a high number of small grains with limited end-use quality. This is confirmed by the results of the current study.

The PGR application responses of neutral and positive effects on grain yield and components of total grain number but negative effects on grain weight are consistent with previous studies where lodging was not problematic (Green, 1986). At some sites (years) the increased yield was due to increased standing power and grain recovery or increased water use efficiency. This is corroborated by the studies of Leitch and Hayes (1990) and Chalmers et al. (1998) on standing power in oat and of Robertson and Greenway (1973) on water use efficiency in wheat. Additive effects of PGR application on grain number are generally associated with a reduction in grain weight to have an ultimately neutral effect on grain yield (Green, 1986). Positive yield responses to PGR in the absence of lodging are uncommon but not unusual. In the current study, panicles $/ \mathrm{m}^{2}$ only increased in response to PGR application in an extremely dry season, whereas grains/panicle increased in response to PGR application in a crop with high panicle numbers. Reductions in grain weight in oats in response to PGR application were reported by Leitch and Hayes (1989) and Browne et al. (2006). This decrease has been linked to an increased sink capacity and an increase in competition between potential grain sites in wheat crops by Lowe and Carter (1972) and Green et al. (1985) noted that chlormequat application reduced the rate of grain growth in the post anthesis period and instead caused redistribution of post anthesis assimilate into non-reproductive organs. It is probable that the reductions in grain weight caused by PGR application were a combination of both responses. 
Table 10. Effect of agronomic factors on post anthesis grain site abortion in winter-sown oats

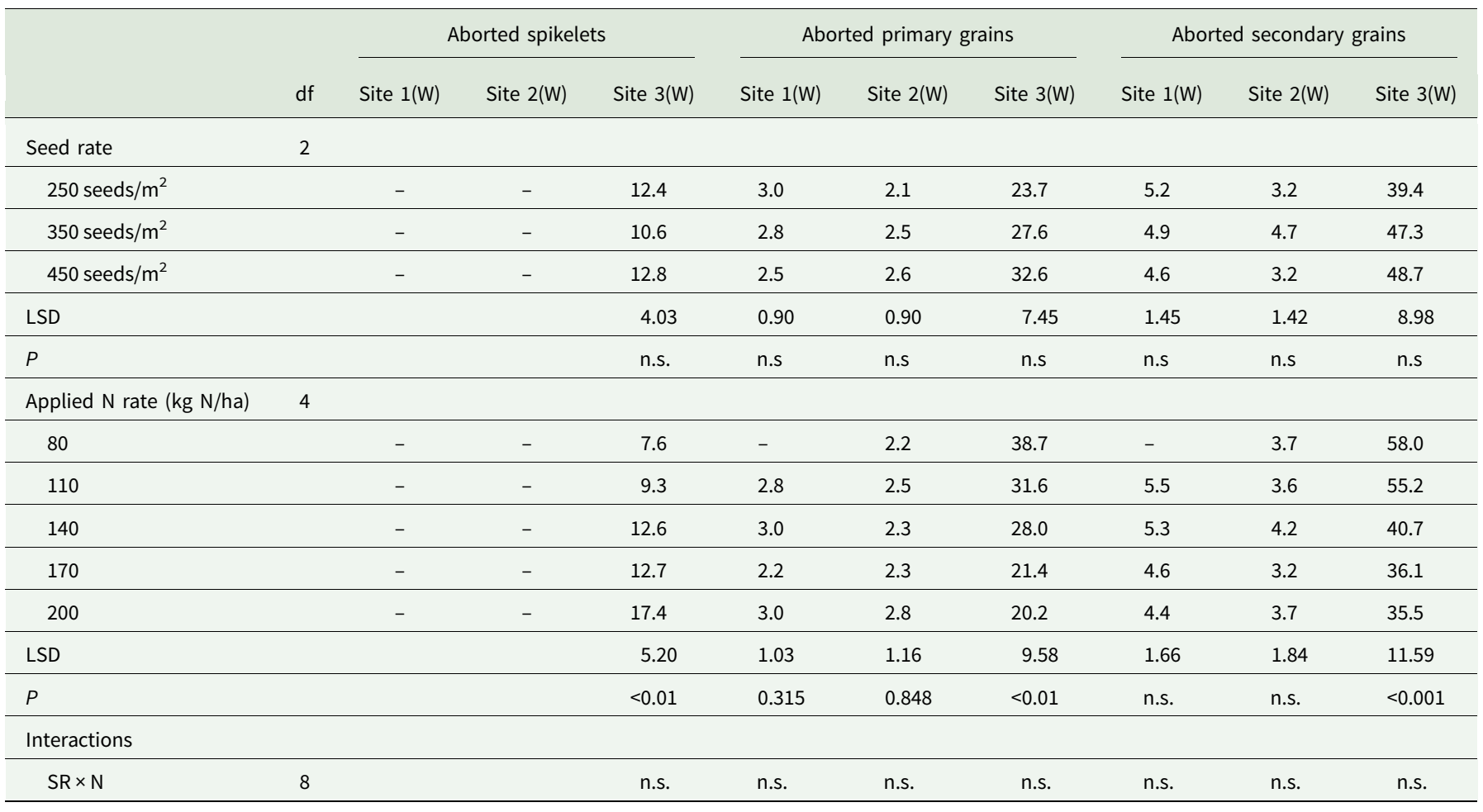

n.s., not significant; N, nitrogen; SR, seed rate.

Values represent total number aborted grain sites per 15 panicles.

Table 11. Correlations between key yield components in spring-sown oats

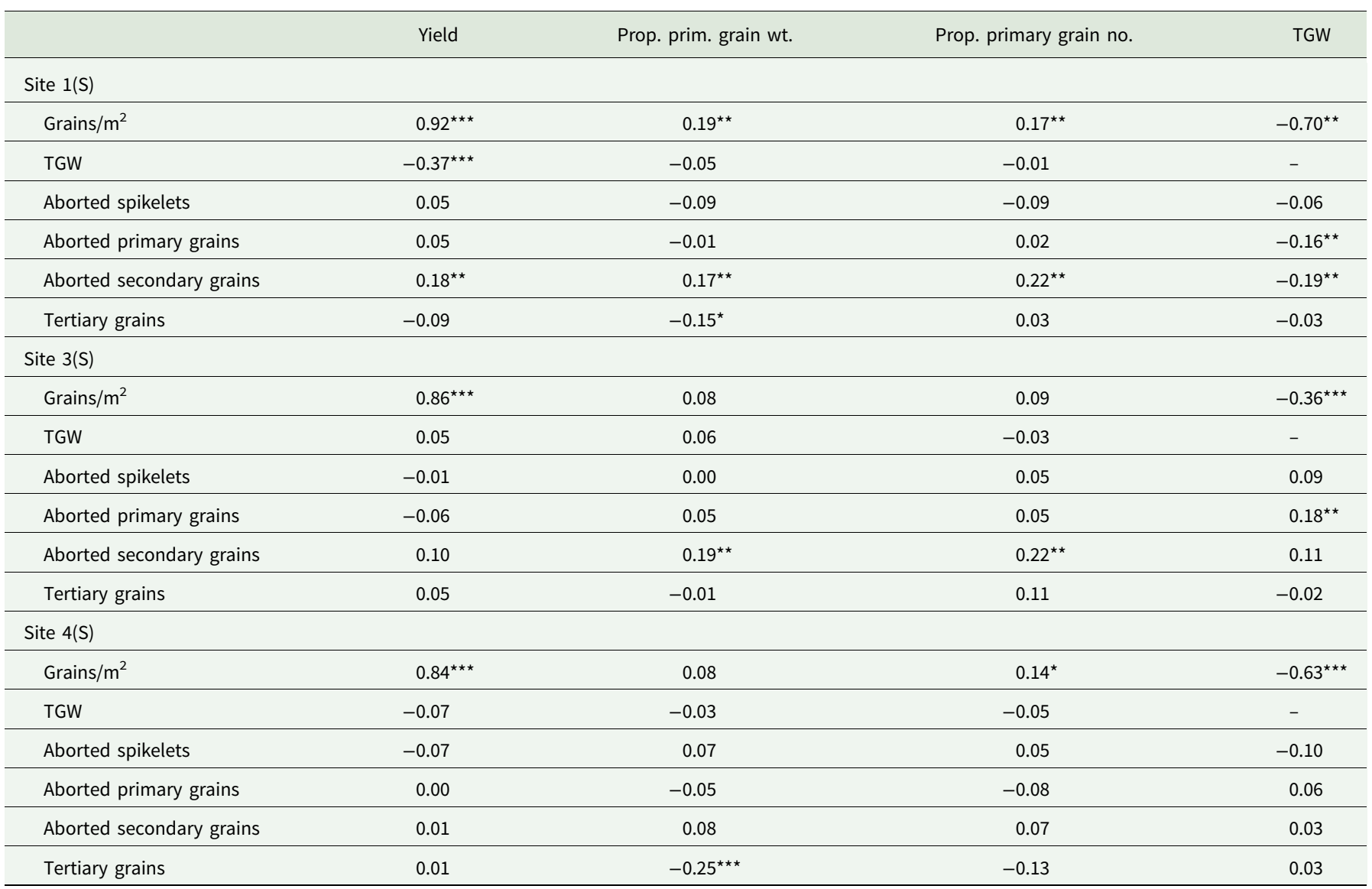

Values indicate Pearson's coefficient of correlation $(r) .{ }^{\star} P<0.05,{ }^{\star \star} P<0.01,{ }^{\star \star \star} P<0.0001$. 
Table 12. Correlations between key yield components in winter-sown oats

\begin{tabular}{|c|c|c|c|c|}
\hline$r$ values & Yield & Prop. prim. grain wt. & Prop. primary grain no. & TGW \\
\hline \multicolumn{5}{|l|}{ Site $1(W)$} \\
\hline Grains $/ \mathrm{m}^{2}$ & $0.73^{\star \star \star}$ & -0.01 & -0.12 & $-0.74^{\star \star \star}$ \\
\hline TGW & $-0.28^{\star}$ & -0.15 & 0.07 & - \\
\hline Aborted spikelets & - & - & - & - \\
\hline Aborted primary grains & 0.04 & $-0.22^{\star}$ & $-0.28^{\star}$ & 0.08 \\
\hline Aborted secondary grains & $-0.41^{\star \star}$ & 0.10 & 0.18 & 0.15 \\
\hline Tertiary grains & - & - & - & - \\
\hline \multicolumn{5}{|l|}{ Site $2(W)$} \\
\hline Grains $/ \mathrm{m}^{2}$ & $0.73^{\star \star \star}$ & -0.02 & -0.09 & $-0.37^{\star \star \star}$ \\
\hline TGW & $0.22^{\star}$ & $-0.38^{\star \star}$ & -0.01 & - \\
\hline Aborted spikelets & - & - & - & - \\
\hline Aborted primary grains & $0.22^{\star}$ & $-0.22^{\star}$ & -0.07 & $0.23^{\star}$ \\
\hline Aborted secondary grains & -0.03 & 0.17 & -0.01 & -0.10 \\
\hline Tertiary grains & $-0.20^{\star}$ & -0.12 & -0.06 & 0.06 \\
\hline \multicolumn{5}{|l|}{ Site $3(W)$} \\
\hline Grains $/ \mathrm{m}^{2}$ & $0.93^{\star \star \star}$ & -0.03 & 0.04 & $-0.33^{\star \star \star}$ \\
\hline TGW & -0.08 & -0.10 & -0.08 & - \\
\hline Aborted spikelets & $0.33^{\star \star}$ & 0.11 & 0.12 & $-0.30^{\star \star}$ \\
\hline Aborted primary grains & $-0.22^{\star}$ & -0.04 & -0.02 & $-0.20^{\star}$ \\
\hline Aborted secondary grains & $-0.27^{\star \star}$ & 0.07 & 0.15 & -0.06 \\
\hline Tertiary grains & $0.23^{\star}$ & $-0.17^{\star}$ & -0.04 & 0.01 \\
\hline
\end{tabular}

Values indicate Pearson's coefficient of correlation $(r) .{ }^{\star} P<0.05,{ }^{\star \star} P<0.01,{ }^{\star \star \star} P<0.0001$.

Where additional grain sites were not stimulated by the application of PGRs it is probable that grain weight was reduced due to assimilate being redirected from grain sites. These results fit in with the theory suggested by Rajala (2004) who, after a wideranging review, concluded that varying responses in oat crops to PGR application were case specific. Although the application of PGR can exert positive effects on yield components, these effects are not as reliable or consistent as other agronomic factors. Therefore, the application of PGR, although required to reduce the risk of crop lodging and increase grain recovery under Irish conditions, should not be claimed as a means of increasing yield per se.

\section{Panicle conformation}

Increasing seed rates resulted in significantly lower spikelet number/panicle in all spring sowings and at sites $1(\mathrm{~W})$ and $2(\mathrm{~W})$ in line with Peltonen-sainio and Jarvinen (1995). Spikelet numbers were unresponsive to increasing $\mathrm{N}$ rate while panicle number was generally higher, indicating that increased $\mathrm{N}$ fertilizer increased panicles $/ \mathrm{m}^{2}$ rather than grains or spikelets per panicle. Increasing the level of applied $\mathrm{N}$ increased the primary grain weight and number ratios in all spring sowings but only increased the primary grain number in one winter sowing. This demonstrated that increases in grains $/ \mathrm{m}^{2}$ in response to increased $\mathrm{N}$ rate were associated with an increase in the proportion of primary grain types. Notably, the results from Browne et al. (2006) where spikelet number and grain number increased while the primary grain number ratio was unaffected, demonstrates that increases in grain number in response to applied $\mathrm{N}$ are not linked to the increased levels of secondary and tertiary grain fills. An interesting response was observed at site $3(\mathrm{~S})$ where the proportion of primary grain by number was $<0.5$. This response initially seems strange, but spikelets and grains/panicle were low at this site relative to other spring-sown sites. A more consistent distribution of assimilates between primary, secondary and tertiary grains is therefore observed at this site, as intra-panicle competition for assimilates is low. This explains the proportion of primary grain number falling below 0.5 , as secondary and tertiary grains outnumbered primary grains.

\section{Grain site abortion}

The influence of agronomic factors on grain site abortion was inconsistent but detectable in all crops and was strongly associated with climatic conditions during grain fill. Oats are unique in that aborted grain sites are easily detectable on the harvested panicle due to the structure of the spikelet, but little published research is available to corroborate this. An important note here is that the presence of grain site abortion in tandem with tertiary grain sites at sites is linked to short stress periods of low assimilate availability during grain fill, rather than overall sink or source limitation. Short, late periods of moisture availability during the period of moisture stress at site $4(\mathrm{~S})$ may have coincided with flowering in tertiary grains, leading to the formation of a high number of 
tertiary grains when no other sinks were available. A high spikelet number/panicle was formed at site $3(\mathrm{~W})$ with a high level of spikelet and grain site abortion observed, as grain fill was limited due to a high potential grain number. Although spikelet abortion increased with the applied $\mathrm{N}$ rate, the negative relationship observed between the applied $\mathrm{N}$ rate and primary/secondary grain abortion demonstrates that an increase in assimilate availability has reduced grain abortion as grain fill progressed. Interestingly, the abortion of spikelets insufficiently readjusted the assimilate balance on the panicle as grain site abortion was still required in a lower number of spikelets.

As the seed rate increased grain site abortion remained similar or decreased at spring-sown sites. This was linked to a lower number of grains/panicle and a higher proportion of mainstems in high seed rate plots which can be adequately filled by the plant. Grain sites on tillers may also be aborted prior to mainstems as competition for assimilates increases during grain fill. Tillers are used as a source of assimilates during pre-anthesis (Peltonen-sainio and Jarvinen, 1995) and may be used in a similar fashion during grain fill due to apical dominance of the mainstem. The application of PGR does not appear to provide any abortion protection and was actually associated with an increase in secondary grain site abortion in one spring crop.

Browne et al. (2006) reported increases in primary and secondary grain site abortion in response to the increased levels of applied $\mathrm{N}$ fertilizer under Irish conditions. The current study provided a more complex pattern of raised and lowered primary and secondary grain site abortion rates and spikelet abortions rates across the different sites/years and sowing dates. Oats produce a higher number of spikelets than they can adequately fill (Peltonen-sainio and Peltonen, 1995) and so the differences in responses can be explained by the differences in the length of the pre-anthesis period between spring- and winter-sown oats, differences in crop growing conditions and the potential of applied $\mathrm{N}$ to increase spikelet number per panicle. For example, the increase in spikelet abortion at site $3(\mathrm{~W})$ can be attributed to a higher initial spikelet number resulting from a longer preanthesis phase in this winter-sown crop and an associated increase in competition from potential grain sites for assimilate immediately following anthesis. The assimilates remobilized from these spikelets in tandem with higher assimilate availability may have contributed to a reduction in primary and secondary grain site abortion as grain fill progressed. This would be less likely to occur in spring-sown oats, as they grow rapidly as daylength increases with a lower number of spikelets formed as a result. Therefore, this explains the observed differential responses between different crops. Increasing the level of $\mathrm{N}$ application would increase assimilate availability and reduce the need for remobilization of nutrients just prior to anthesis, with the extension of the grain fill period lowering abortion rates amongst a lower number of spikelets in spring-sown crops. Similarly, the early abortion of surplus spikelets in the winter-sown crops reduced the level of demand from grain sites with the longer period of grain fill better equipped to increase grain fill amongst a smaller pool of potential grain sites. The differential responses in the spring-sown crops is also understandable, as Browne et al. (2006) have shown that the grain fill period in spring crops is shorter with abortion of grain sites required to ensure consistent grain fill within the remaining spikelets on the panicle. Therefore, it can be concluded that the effect of applied $\mathrm{N}$ rate on grain site abortion is highly linked to climatic conditions and the physiological time at which assimilate becomes limiting.
There is a hierarchal ranking for abortion of grain sites during the development of the oat panicle, which proceeds from the uppermost terminal spikelet to the base of the panicle with pollination proceeding in the same order across a period of 10-11 days (Rajala and Peltonen-Sainio, 2011). Grains at the uppermost whorl are also typically bigger than grains from whorls closer to the base (White and Finnan, 2017). This can lead to a situation where grains at the uppermost panicle have moved through anthesis with grains at the lowest whorl only commencing anthesis. In crops characterized by a high spikelet number the demand for assimilates from grains at the uppermost whorl may trigger the abortion of spikelets at an early development stage. Once the plant has determined its total fertile spikelet number it begins the allocation of assimilates into primary and secondary florets within each spikelet. Finnan and Spink (2017) note that increases in grain number due to a higher spikelet number per panicle is not predominantly linked with an increase in the number of secondary grains per spikelet, noting the potential for a high number of single-grain spikelets. The underlying multifaceted nature of this fluid relationship between abortion and maintenance of grain yield is clearly associated with the pattern of correlations observed between the key yield components, and so provides a unique insight into these processes.

Overall, the current study firmly reinforces the theory of elasticity of grain fill proposed by Browne et al. (2006). The associations between the proportion of primary grain weight and aborted secondary grains indicate that yield was source limited. The winter-sown sites are of high importance in this respect. Where grain yield was at its highest secondary grain abortion was low and all available grain sites were then filled, leading to the high yield achieved. During the period of moisture stress at site 2 (W), when primary grain site abortion was significantly associated with grain yield, this indicates that remobilization of assimilates had occurred to maintain total grain yield. These results also support a hierarchy of grain fill during the periods of assimilate shortages with primary grain florets preferred. In order to achieve maximum yield levels, a consistent level of secondary grain fill is required, demonstrated by the results from site $1(\mathrm{~W})$. Griffiths (2010) reported that the primary grain weight ratio was negatively correlated with grain yield $(r=-0.65)$ noting that a high degree of secondary grain fill was required to achieve high yields. This is applicable when climatic and agronomic conditions are at their optimum during grain fill as all grain sites can be adequately filled, such as site $1(\mathrm{~W})$. In cases where the plant lacks the photosynthetic capacity to fill all its grains, grain sites were aborted to ensure consistent grain fill within a smaller pool of potential grain sites.

\section{Conclusion}

Increases in panicle number accounted for yield increases in response to seed rate and $\mathrm{N}$ rate regardless of sowing date. This study demonstrated that oat grain yield under cool, humid conditions is associated with high levels of secondary grain fill. During seasons characterized by moisture stress, grain site abortion played a key role in the maintenance of crop yield by ensuring a base level of primary grain fill within each spikelet. Once the number of fertile spikelets is determined at anthesis, assimilate allocation is prioritized for primary grains to ensure at least one per spikelet survives. This study has also demonstrated an important relationship between spikelet number at anthesis and the suitability of grain fill conditions on the processes of grain site 
formation and the post-anthesis abortion of grain sites. A continued move to winter sowing will improve the yield potential and consistency of crop performance under Irish conditions.

Supplementary material. The supplementary material for this article can be found at https://doi.org/10.1017/S0021859621000320.

Acknowledgements. The authors thank Mr Eugene Brennan.

Financial support. This study was supported by Irish Research Council and Origin Enterprises PLC.

Conflict of interest. The authors declare there are no conflicts of interest.

\section{References}

Baethgen WE, Christianson CB and Lamothe AG (1995) Nitrogen fertilizer effects on growth, grain yield and yield components of malting barley. Field Crops Research 43, 87-99.

Brinkman MA and Rho YD (1984) Response of three oat cultivars to N fertilizer. Crop Science 24, 973-977.

Browne RA, White EM and Burke JI (2003) Effect of nitrogen, seed rate and plant growth regulator (chlormequat chloride) on the grain quality of oats (Avena sativa). Journal of Agricultural Science 141, 249-258.

Browne RA, White EM and Burke JI (2006) Responses of developmental yield formation processes in oats to variety, nitrogen, seed rate and plant growth regulator and their relationship to quality. Journal of Agricultural Science 141, 533-545.

Buerstmayr H, Krenn N, Stephan U, Grausgruber H and Zechner E (2007) Agronomic performance and quality of oat (Avena sativa L.) genotypes of worldwide origin produced under central European growing conditions. Field Crops Research 101, 343-351.

Burke JI, Browne RA and White EM (2001) Factors affecting yield and quality of oats. Teagasc, Crop Research Centre, Oak Park Carlow. Project report 4493. No. 32. ISBN 184170207 2. Available at http://hdl.handle.net/11019/ 1390.

Calderini DF, Dreccer MF and Slafer GA (1997) Consequences of breeding on biomass, radiation interception and radiation-use efficiency in wheat. Field Crops Research 52, 271-281.

Chalmers AG, Dyer CJ and Sylvester-Bradley R (1998) Effects of nitrogen fertilizer on the grain yield and quality of winter oats. Journal of Agricultural Science 131, 395-407.

Crampton MW, Moot DJ and Martin RJ (1997) Kernel Weight Distributions between oat (Avena Sativa L.) Panicles. Proceedings Annual Conference Agronomy Society of New Zealand, 27, pp. 83-87. Soil, Plant and Ecological Sciences Division, PO Box 84, Lincoln University, Canterbury, New Zealand.

Deane D and Commers E (1986) Oat cleaning and processing. In Webster F (ed), Oats: Chemistry and Technology. St. Paul: American Association of Cereal Chemists, pp. 371-412.

Doehlert DC, McMullen MS and Riveland NR (2002) Sources of variation in oat kernel size. Journal of Cereal Chemistry 79, 528-534.

Doehlert DC, McMullen MS, Jannick J-L, Panigrahi S, Gu H and Riveland NR (2004) Evaluation of oat kernel size uniformity. Crop Science 44, $1178-1186$.

Doehlert D, McMullen M, Jannink J, Panigrahi S, Gu H and Riveland N (2005) A bimodal model for oat kernel size distributions. Canadian Journal of Plant Science 85, 317-326.

Easson DL (1984) The timing of nitrogen application for spring barley. The Journal of Agricultural Science 102, 673-678.

Efretui A, Gooding M, White E, Spink J and Hackett R (2016) Effect of nitrogen fertilizer application on nitrogen use efficiency and grain yield of winter wheat in Ireland. Irish Journal of Agricultural and Food Research 55, 63-73.

Ellen J and Spiertz JH (1980) Effects of rate and timing of nitrogen dressings on grain yield formation of winter wheat ( $T$. aestivum L.). Fertilizer Research 1, 177-190.
Finnan JM and Spink J (2017) Identification of yield limiting phenological phases of oats to improve crop management. Journal of Agricultural Science 155, 1-17.

Finnan J, Hyland L and Burke B (2018) The effect of seeding rate on radiation interception, grain yield and grain quality of autumn sown oats. European Journal of Agronomy 101, 239-247.

Finnan J, Burke B and Spink J (2019a) The plasticity of the oat panicle and associated changes in leaf area and grain weight. Field Crops Research $\mathbf{2 4 2}$ doi:10.1016/j.fcr.2019.107592.

Finnan J, Burke B and Spink J (2019b) The effect of nitrogen timing and rate of application on radiation interception, grain yield and grain quality in autumn sown oats. Field Crops Research 231, 130-140.

Green CF (1986) Modifications to the growth and development of cereals using chlorochlorine chloride in the absence of lodging: a synopsis. Field Crops Research 14, 117-133.

Green CF, Hawkins TC and McDonald HG (1985) Influence of chlorocholine chloride on grain growth of winter barley (Hordeum distichon L. cv. Igri) in the field. Journal of Experimental Botany 36, 1125-1133.

Griffiths I (2010) Dissecting the Yield Components of Oats. Institute of Biological, Environmental \& Rural Sciences (IBERS) and Aberynswynth University: HGCA.

Hay RK and Walker AJ (1989) An Introduction to the Physiology of Crop Yield (Vol. 1). Harlow, England: Longman Scientific and Technical.

Kirby E and Appleyard M (1984) Cereal plant development and its relation to crop management. In Gallagher E (ed.), Cereal Production, pp. 161-173. Butterworths, London.

Leitch MH and Hayes JD (1989) Effect of chlormequat application on stem characteristics, yield and panicle conformation of winter oats. Journal of Agricultural Science 113, 17-26.

Leitch MD and Hayes RD (1990) Effects of single and repeated applications of chlormequat on early crop development, lodging resistance and yield of winter oats. The Journal of Agricultural Science 115, 11-14.

Lowe LB and Carter OG (1972) The influence of CCC (2-chloroethylthyltrimethyl-ammonium chloride) and temperature on dry matter and assimilate accumulation in wheat. Australian Journal of Agricultural Research 23, 573-583.

Lynch P and Frey K (1993) Genetic improvement in agronomic and physiological traits of oat since 1914. Crop Science 33, 984-988.

Mahadevan M, Calderini DF, Zwer PK and Sadras VO (2016) The critical period for yield determination in oat (Avena sativa L.). Field Crops Research 199, 109-116.

Marshall A, Cowan S, Edwards S, Griffiths I, Howarth C, Langdon T and White E (2013) Crops that feed the world 0. Oats - a cereal crop for human and livestock feed with industrial applications. Food Security 5, $13-33$.

Met Eireann (2020) Available at https://www.met.ie. Retrieved 23 June 2020.

Miralles DJ and Slafer GA (2007) Sink limitation to yield in wheat: how could it be reduced? Journal of Agricultural Science 145, 139-149.

Ohm HW (1976) Response of 21 oat cultivars to nitrogen fertilization. Agronomy Journal 68, 773-775.

Palta JA, Kobata T, Turner NC and Fillery IR (1994) Remobilization of carbon and nitrogen in wheat as influenced by post-anthesis water deficits. Crop Science 34, 118-126.

Pecio A and Bichonski A (2010) Nitrogen fertilization and fungicide application as elements of oat production. Polish Journal of Environmental Studies 19, 1297-1305.

Peltonen-Sainio P and Jarvinen P (1995) Seeding rate effects on tillering, grain yield and yield components of oat at high latitude. Field Crops Research 40, 49-56.

Peltonen-Sainio P and Peltonen J (1995) Floret set and abortion in oat and wheat under high and low nitrogen regimes. European Journal of Agronomy 4, 253-262.

Peltonen-Sainio P, Forsman K and Poutala P (1997) Crop management effects on pre- and post anthesis changes in leaf area index and leaf area duration and their contribution to grain yield and yield components in spring cereals. Journal of Agronomy and Crop Science 179, 47-61.

Peltonen-Sainio P, Kangas A, Salo Y and Jauhiainen L (2007) Grain number dominates grain weight in temperate cereal yield determination: evidence 
based on 30 years of multi-location trials. Field Crops Research 100, 179-188.

Rajala A (2004) Plant growth regulators to manipulate oat stands. Journal of Agricultural and Food Science 13, 186-197.

Rajala A and Peltonen-Sainio P (2011) Pollination dynamics, grain weight and grain cell number within the inflorescence and spikelet in oat and wheat. Agricultural Sciences 2, 283-290.

Reynolds S, Hill A, Thomas M and Hamey P (2004) Occurrence and risks associated with chlormequat residues in a range of foodstuffs in the UK. Food Additives and Contaminants 21, 457-471.

Robertson GA and Greenway H (1973) Effects of CCC on drought resistance of Triticum aestivum L. and Zea mays L. Annals of Botany 37, 929-934.

Sadras V (2007) Evolutionary aspects of the trade-off between seed size and number in crops. Field Crops Research 100, 125-138.

Symons SJ and Fulcher RG (1988) Determination of variation in oat kernel morphology by digital image analysis. Journal of Cereal Science 7, 219-228.

Takeda K and Frey KJ (1980) Tertiary seed set in oat cultivars. Crop Science 20, 771-774.
Wall P and Cartwright P (1976) Effects of photoperiod, temperature and vernalisation on phenology and spikelet numbers of spring wheat. Annals of Applied Biology 76, 299-309.

Wall DP and Plunkett M (2016) Major and Micro Nutrient Advice for Productive Agricultural Crops (4th ed.). Johnstown Castle, Wexford: Teagasc.

White EM (1995) Structure and development of oats. In Welch RW (ed.), The Oat Crop: Production and Utilization. London: Chapman \& Hall, pp. 88-119.

White E and Finnan J (2017) Crop structure in winter oats and the effect of nitrogen on quality related parameters. Journal of Crop Improvement 31, 758-779.

White E and Watson S (2010) An investigation of the relationship between hullability and morphological features in grains of four oat varieties. Annals of Applied Biology 156, 281-295.

White EM, Mc Garel AS and Ruddle O (2003) The influence of variety, year, disease control and plant growth regulator application on crop damage, yield and quality of winter oats (Avena sativa). Journal of Agricultural Science 140, 31-42.

Zadoks JC, Chang TT and Konzak CF (1974) A decimal code for the growth stage of cereals. Weed Research 14, 415-421. 